\title{
RURAL BANK AND REGIONAL ECONOMIC DEVELOPMENT: EVIDENCE FROM INDONESIA
}

\author{
Jamal Wiwoho \\ Faculty of Law, Universitas Sebelas Maret, Indonesia
}

\begin{abstract}
Nugroho Saputro
Faculty of Economics and Business and Center for Fintech and Banking, Universitas Sebelas Maret, Indonesia

\section{Putra Pamungkas}

Faculty of Economics and Business and Center for Fintech and Banking, Universitas Sebelas Maret, Indonesia

\section{Irwan Trinugroho*}

Faculty of Economics and Business and Center for Fintech and Banking, Universitas Sebelas Maret, Indonesia

\section{Moch. Doddy Ariefianto}

Accounting Department, BINUS Graduate Program-Master Accounting, Bina Nusantara University, Indonesia
\end{abstract}

\section{Francisca Sestri Goestjahjantie \\ STIE Insan Pembangunan, Indonesia}

\begin{abstract}
This paper investigates the relationship between fund reallocation on economic growth and poverty by using 1860 rural banks. Our quarterly data allow us to merge bank-level data and province level-data from 20102016. We find that loan-to-deposit ratio as our proxy of intermediation function could boost economic development. Our non-linear regression shows that too much finance reduces regional GDP growth but, in the long term, could help to reduce poverty. Our results provide some important policy implications that rural banks could contribute to economic development in a good way but should be highly supervised in terms of risk and competition.
\end{abstract}

Keywords: Rural Bank, Fund Allocation, Economic Growth, Poverty, Indonesia.

Received:12 January 2021

Accepted:10 May 2021

https://doi.org/10.33736/ijbs.3761.2021

\footnotetext{
- Corresponding author: Faculty of Economics and Business and Center for Fintech and Banking, Universitas Sebelas Maret, Indonesia; Tel: +628112540689; Email: irwan_t@staff.uns.ac.id
} 


\section{INTRODUCTION}

The relationship between finance, economic activities, and economic development has been a longstanding issue and well-established in banking literature (Beck et al., 2015; Donou-Adonsou \& Sylwester, 2016; Hassan et al., 2011; Park \& Shin, 2017). Beck et al. (2015) especially examine the finance-growth nexus for microenterprises in China and find that access to finance is positively associated with entrepreneurship. Microfinance institutions play a significant role in financial intermediation especially in providing financial access to micro and small enterprises.

One of the microfinance institutions is rural banks which can operate on the conventional or Sharia basis. Rural bank as a financial intermediary institution has a role in reallocating the fund from society to fund the entrepreneur in all productive sectors, especially micro and small enterprises. Although the rural bank is relatively small, it contributes to economic development and has an advantage in the relationship with the client (Berger et al., 2014). Rural bank plays an important role in the Indonesian economy. Otoritas Jasa Keuangan (the Indonesia Financial Services Authority) shows in its Indonesian Banking Booklet 2020 that, by December 2019, the assets of Indonesian rural banks are IDR 149.623 Billion. Rural banks have a vital position in the Indonesian economy because around $99 \%$ of businesses in Indonesia can be classified as small and micro businesses, and Rural employment covers almost half the Indonesian population and contributes more than $40 \%$ of the country's gross domestic product (GDP) (Shaban et al., 2014). As a dual banking market, there are two types of rural bank: Islamic and conventional rural banks. However, Islamic rural bank has small share due to the limited business activities and operational areas (small and medium-sized enterprises and local community) compared to commercial banks, which can reach any segment of the banking market (Trinugroho et al., 2018). As a prominent emerging country with a bank-based financial system, Indonesia faces high inequality in several aspects. Based on World Bank Financial Inclusion 2014 report, only 36\% of around 260 million people have access to finance, and 28 million people live in poverty. Therefore, it is interesting to see how rural banks contribute to economic growth and poverty alleviation.

This paper investigates the relationship between intermediation function measure by the capacity of rural banks to reallocate the deposit into lending and GDP growth and poverty as a proxy of economic development. We use detailed data that consist of 1860 rural banks in 34 provinces in Indonesia. Literature shows that the presence of rural banks has a positive impact on economic development, specifically in the intermediate and less developed areas (Meslier-Crouzille et al., 2012). Rural bank fills the gap of the reluctance of commercial banks to lend to SMEs in the market. They also significantly reduce rural poverty in the unbanked areas (Burgess \& Pande, 2005). We contribute to the literature by investigating the intermediation capacity of the rural bank on economic development using a significant number of rural bank data across provinces in Indonesia. Our study close to Chang et al. (2010) that use loan to deposit ratio (LDR) as a measurement of bank fund reallocation. We find that the relationship between LDR and regional GDP growth and poverty is non-linear with the form inverted U-shaped. It indicates that in the beginning, LDR increases regional GDP then later reduces regional GDP. For poverty, LDR increases poverty, but after reaching the threshold point, it reduces poverty. Consistent with the literature, finance-growth nexus that find too much credit is detrimental to economic growth (Hook \& Singh, 2014; Soedarmono et al., 2017). 
The rest of the paper is organized as follows. Section 2 and 3 present the literature review and data methodology. Section 4 describes results, and section 5 provides concluding remarks.

\section{LITERATURE REVIEW}

Many studies have taken an interest in bank fund reallocation and regional economic growth. Chang et al. (2010) find that there is no correlation between bank fund reallocation and regional economic growth or between bank loans and regional economic growth. However, a positive association between bank deposits and growth. It appears economic growth leads to financial development in China, not the other way around. Furthermore, as China's market-oriented reforms deepen, fund reallocation and loans start to manifest positive effects on growth even though the banks are government-owned.

While Banto and Monsia (2020) analyze the statistical significance of MFIs' and banks' performance on economic development through a GMM panel analysis between 1999 to 2016, their main contribution to previous literature is twofold. Firstly, they consider a greater variety of indicators to capture different aspects of the banks' and MFIs' performance. Secondly, besides traditional channels of transmission such as investment and human capital, they account for an important potential transmission channel, which is consumption. They mainly find that MFIs' performance contributes to economic development despite their relatively small size even when banks' performance is taken into account. Furthermore, the results suggest that by improving their social and financial performance, MFIs increase investment and consumption. Especially, they show that women use their loans to consume rather than to invest. Finally, they also find that banks' performance improves GDP per capita through investment, consumption, and human capital.

Financial development disproportionately boosts incomes of the poorest quintile and reduces income inequality. About $40 \%$ of the long-run impact of financial development on the income growth of the poorest quintile is the result of reductions in income inequality, while $60 \%$ is due to the impact of financial development on aggregate economic growth. Furthermore, financial development is associated with a drop in the fraction of the population living on less than $\$ 1$ a day, a result that holds when conditioning on average growth. The findings emphasize the importance of the financial system for the poor (Beck et al., 2007).

Hasan et al. (2009) test whether regional growth in 11 European countries depends on financial development and suggest using cost- and profit-efficiency estimates as quality measures of financial institutions. Contrary to the usual quantitative proxies of financial development, the quality of financial institutions is measured as the relative ability of banks to intermediate funds. An improvement in bank efficiency spurs five times more regional growth than an identical increase in credit does. More credit provided by efficient banks exerts an independent growth effect in addition to direct quantity and quality channel effects.

Hassan et al. (2011) provide evidence on the role of financial development in accounting for economic growth in low- and middle-income countries classified by geographic regions. To document the relationship between financial development and economic growth, they estimate both panel regressions and variance decompositions of annual GDP per capita growth rates. To 
examine what proxy measures of financial development are most important in accounting for economic growth over time and how much they contribute to explaining economic growth across geographic regions and income groups. They find a positive relationship between financial development and economic growth in developing countries. Moreover, the short-term multivariate analysis provides mixed results: a two-way causality relationship between finance and growth for most regions and one-way causality from growth to finance for the two poorest regions. Furthermore, other variables from the real sector, such as trade and government expenditure, play an important role in explaining economic growth. Therefore, it seems that a well-functioning financial system is a necessary but not sufficient condition to reach steady economic growth in developing countries.

Hook and Singh (2014) provides new evidence on the relationship between finance and economic growth using an innovative, dynamic panel threshold technique. The sample consists of 87 developed and developing countries. The empirical results indicate that there is a threshold effect in the finance growth relationship. In particular, they find that the level of financial development is beneficial to growth only up to a certain threshold; beyond the threshold level, further development of finance tends to adversely affect growth. These findings reveal that more finance is not necessarily good for economic growth and highlight that an "optimal" level of financial development is more crucial in facilitating growth.

Most finance growth studies approximate the size of financial systems rather than the quality of intermediation to explain economic growth differentials. Furthermore, the neglect of systematic differences in cross-country studies could drive the result that finance matters. They suggest a measure of bank's intermediation quality using bank-specific efficiency estimates and focus on the regions of one economy only: Germany. This quality measure has a significantly positive effect on growth. This result is robust to the exclusion of banks operating in multiple regions, controlling for the proximity of financial markets, distinguishing different banking sectors active in Germany, and excluding the structurally weaker East from the sample (Koetter \& Wedow, 2010).

Park and Shin (2017) find that financial development contributes to lower inequality up to a point, but as financial development proceeds further, it contributes to higher inequality. We also find that when the ratio of primary schooling to total schooling increases and law and order improves financial development becomes more effective in reducing inequality. Finally, we find that financial inclusion is particularly effective in lowering income inequality.

According to Soedarmono et al. (2017), which study the finance growth nexus in a single developing country where bank credit is decomposed into investment, consumption, and working capital credit. From a panel dataset of provinces in Indonesia, they document that higher financial development as measured by financial deepening and financial intermediation exhibits an inverted U-shaped relationship with economic growth. This non-linear effect of financial deepening is driven by investment credit and consumer credit, while the financial intermediation is mostly driven by investment credit. These results suggest that too much investment credit (to a lesser extent, consumption credit) is detrimental to economic growth. Ultimately, only financial intermediation associated with working capital credit has a positive and monotonic impact on economic growth. 


\section{METHODOLOGY}

We examine the finance and economic development nexus by using detailed data of rural banks in Indonesia. Our data consist of 1860 rural banks located across 34 provinces in Indonesia. Our detailed data allow us to merge bank-level data and province level-data from quarter 22010 to quarter 3 2016. We combine the rural bank-level data with provinces-level data that are retrieved from the Indonesia Statistics Office (BPS) and the dataset on Indonesian rural banking provided by the Indonesia Deposit Insurance Corporation (LPS) and the Indonesia Financial Services Authority (OJK). Table 1 exhibits the definition of each variable and provides the descriptive statistics of variables, and Table 2 show the distribution of rural bank by province.

Table 1: Statistics Descriptive

\begin{tabular}{|c|c|c|c|c|c|c|}
\hline Variable & Definition & Obs & Mean & $\begin{array}{l}\text { Std. } \\
\text { Dev. }\end{array}$ & Min & Max \\
\hline GDRP & Regional GDP growth & 47,663 & 5.690 & 1.707 & -13.715 & 21.760 \\
\hline lnpoverty & $\begin{array}{c}\text { natural logarithm of } \\
\text { poverty }\end{array}$ & 48,022 & 7.324 & 1.321 & 5.105 & 8.594 \\
\hline $\operatorname{ldr}$ & loan to deposit ratio & 40,374 & 80.070 & 12.067 & 57.190 & 95.970 \\
\hline roa & return on asset & 40,408 & 3.506 & 3.098 & -1.000 & 9.000 \\
\hline NPL & non-performing loan & 40,365 & 5.624 & 4.835 & 0.510 & 15.640 \\
\hline car & capital-adequacy ratio & 40,361 & 28.337 & 16.500 & 11.000 & 62.540 \\
\hline $\begin{array}{c}\text { Bank_Densit } \\
y\end{array}$ & $\begin{array}{l}\text { bank concentration. } \\
\text { Population divided by } \\
\text { bank branch. }\end{array}$ & 48,020 & 30.047 & 11.125 & 14.441 & 48.058 \\
\hline $\operatorname{lnta}$ & natural logarithm of & 40,373 & 16.638 & 0.987 & 15.138 & 18.291 \\
\hline eqta & equity to total asset & 40,299 & 0.232 & 0.187 & 0.017 & 0.625 \\
\hline Inflation & inflation rate & 42,948 & 0.272 & 0.566 & -3.430 & 5.320 \\
\hline
\end{tabular}

Table 2: Number of Rural Banks by Province

\begin{tabular}{lcc}
\hline \multicolumn{1}{c}{ Province } & $\begin{array}{c}\text { Number of rural } \\
\text { banks }\end{array}$ & Percentage \\
\hline Province Bali & 145 & 7.85 \\
Province Banten & 76 & 4.11 \\
Province Bengkulu & 4 & 0.22 \\
Province D.I Yogyakarta & 55 & 2.98 \\
Province DKI Jakarta & 42 & 2.25 \\
Province Gorontalo & 3 & 0.16 \\
Province Jambi & 21 & 1.14 \\
Province Jawa Barat & 356 & 19.25 \\
Province Jawa Tengah & 294 & 15.92 \\
Province Jawa Timur & 346 & 18.75 \\
Province Kalimantan Barat & 24 & 1.3 \\
Province Kalimantan Selatan & 26 & 1.41 \\
Province Kalimantan Tengah & 4 & 0.22 \\
Province Kalimantan Timur & 15 & 0.81 \\
Province Kep. Bangka Belitung & 2 & 0.11 \\
Province Kep. Riau & 44 & 2.38 \\
Province Kepulauan Riau & 1 & 0.05
\end{tabular}


Province Lampung

Province Maluku

Province Maluku Utara

Province NAD

Province Nusa Tenggara Barat

Province Nusa Tenggara Timur

Province Papua

Province Papua Barat

Province Riau

Province Sulawesi Barat

Province Sulawesi Selatan

Province Sulawesi Tengah

Province Sulawesi Tenggara

Province Sulawesi Utara

Province Sumatera Barat

Province Sumatera Selatan

Province Sumatera Utara

\begin{tabular}{cc}
29 & 1.57 \\
2 & 0.11 \\
2 & 0.11 \\
6 & 0.31 \\
31 & 1.68 \\
12 & 0.65 \\
6 & 0.32 \\
1 & 0.05 \\
33 & 1.78 \\
1 & 0.05 \\
22 & 1.19 \\
10 & 0.54 \\
19 & 1.03 \\
18 & 0.97 \\
109 & 5.9 \\
24 & 1.3 \\
62 & 3.36 \\
\hline
\end{tabular}

We use standard panel data regression to estimate our data following several studies in financegrowth nexus. The following is our baseline model:

$$
G D P / \text { Poverty }_{p, t}=\alpha+\beta_{1} L D R_{p, t}+\text { Control Variables }+\varepsilon_{p, t}
$$

Our dependent variable regional economic development is measured by regional GDP growth and logarithm natural of the number of people living in poverty in a province. Our main variable of interest is loan-to-deposit ratio that measured the capacity of rural banks to transform the available fund into lending to their regional area. We expect that the more ability of intermediation function in a rural bank, the more economic growth and the less poverty in a province that the rural bank is located.

Our control variables are return on asset to measure the performance of rural banks, nonperforming loans to gauge the riskiness of rural banks, CAR to capture the capitalization of rural banks, bank density to show the competition of financial services in a province. We also use logarithm natural of total asset and equity to total asset to measure the size of each rural bank, and we include inflation rate to control provinces. We also included provinces fixed in effect in regression.

To better understand the impact of LDR in the long term and as robustness check, we test the nonlinear relationship of LDR following Soedarmono et al. (2017) and Hook and Singh (2014) that test the non-linearity in finance-growth nexus literature. With some adjustment, the following is the estimation model:

$$
G D P / \text { Poverty } y_{p, t}=\alpha+\beta_{1} L D R_{p, t}+\beta_{2} L D R 2_{p, t}+\text { Control Variables }+\varepsilon_{p, t}
$$




\section{RESULTS AND DISCUSSION}

We investigate the effect of loan-deposit-ratio on economic development measured by regional GDP growth and poverty. The results are provided in table 2 with several types of panel data regression of OLS with rural bank fixed effect, random effect, and fixed effect. Our baseline model shows that the financial intermediation function measured by LDR increases poverty in OLS regression. It implies that too much finance is harmful to economic development in line with the study of Hook and Singh (2014) and Soedarmono et al. (2017). We find that LDR is not significant associated with regional GDP. This results in line we the findings of Chang et al. (2010).

We find in our control variable that non-performing loans as a proxy of risk have a negative and significant relationship on GRDP and positive and significant relationships. It means that risk could reduce GDP growth and increase poverty. It implies that the better rural banks are, the better economic development.

Table 3: Baseline Regression

\begin{tabular}{|c|c|c|c|c|c|c|}
\hline & $\begin{array}{c}\text { OLS } \\
\text { GDRP }\end{array}$ & $\begin{array}{c}\text { OLS } \\
\text { lnpoverty }\end{array}$ & $\begin{array}{c}\text { RE } \\
\text { GDRP }\end{array}$ & $\begin{array}{c}\mathrm{RE} \\
\text { lnpoverty }\end{array}$ & $\begin{array}{c}\text { FE } \\
\text { GDRP }\end{array}$ & $\begin{array}{c}\mathrm{FE} \\
\text { lnpoverty }\end{array}$ \\
\hline $\mathrm{Ldr}$ & $\begin{array}{c}0.0000346 \\
(0.04)\end{array}$ & $\begin{array}{c}0.00246^{* * *} \\
(4.10)\end{array}$ & $\begin{array}{c}-0.000683 \\
(-0.55)\end{array}$ & $\begin{array}{c}-0.0000396 \\
(-0.75)\end{array}$ & $\begin{array}{c}-0.000314 \\
(-0.24)\end{array}$ & $\begin{array}{c}-0.0000407 \\
(-0.77)\end{array}$ \\
\hline Roa & $\begin{array}{c}-0.0157^{* * * *} \\
(-4.43)\end{array}$ & $\begin{array}{c}0.0750^{* * * *} \\
(31.02)\end{array}$ & $\begin{array}{c}-0.0269^{* * * *} \\
(-4.51)\end{array}$ & $\begin{array}{c}0.000133 \\
(0.48)\end{array}$ & $\begin{array}{c}-0.0254^{* * * *} \\
(-3.90)\end{array}$ & $\begin{array}{c}0.000113 \\
(0.41)\end{array}$ \\
\hline NPL & $-0.00670^{* * * *}$ & $0.0107^{* * * *}$ & 0.00461 & $0.000575^{* * *}$ & 0.00737 & $0.000574^{* *}$ \\
\hline & $(-3.22)$ & (6.94) & (1.11) & (2.95) & $(1.60)$ & $(2.94)$ \\
\hline Car & -0.000490 & $0.00383^{* * *}$ & 0.000571 & 0.00000662 & -0.000579 & $\begin{array}{c}0.0000058 \\
6 \\
(0.08)\end{array}$ \\
\hline Bank_Density & $\begin{array}{c}-0.0147^{* * * *} \\
(-18.80)\end{array}$ & $\begin{array}{c}0.00542^{* * * *} \\
(8.49)\end{array}$ & $\begin{array}{c}-0.0218^{* * * *} \\
(-7.76)\end{array}$ & $\begin{array}{c}0.0131^{* * * *} \\
(32.35)\end{array}$ & $\begin{array}{c}-0.0406^{* * * *} \\
(-3.47)\end{array}$ & $\begin{array}{c}0.0131^{* * * *} \\
(32.34)\end{array}$ \\
\hline lnta & $\begin{array}{c}-0.0144 \\
(-1.00)\end{array}$ & $\begin{array}{c}0.0000328 \\
(0.00)\end{array}$ & $\begin{array}{c}0.262^{* * * *} \\
(9.04)\end{array}$ & $\begin{array}{c}-0.00304 \\
(-1.00)\end{array}$ & $\begin{array}{c}0.488^{\text {***** }} \\
(8.77)\end{array}$ & $\begin{array}{c}-0.00305 \\
(-1.00)\end{array}$ \\
\hline eqta & $\begin{array}{c}-0.0180 \\
(-0.25)\end{array}$ & $\begin{array}{c}-0.546^{* * * *} \\
(-10.10)\end{array}$ & $\begin{array}{c}0.0329 \\
(0.24)\end{array}$ & $\begin{array}{c}0.0334^{* * * *} \\
(3.63)\end{array}$ & $\begin{array}{c}0.0713 \\
(0.42)\end{array}$ & $\begin{array}{c}0.0336^{* * * *} \\
(3.64)\end{array}$ \\
\hline Inflation & $\begin{array}{c}-0.000448 \\
(-0.02)\end{array}$ & $\begin{array}{c}0.136^{* * * *} \\
(10.43)\end{array}$ & $\begin{array}{c}0.00159 \\
(0.14)\end{array}$ & $\begin{array}{c}-0.00153^{* * *} \\
(-2.41)\end{array}$ & $\begin{array}{c}-0.00123 \\
(-0.11)\end{array}$ & $\begin{array}{c}-0.00154^{* *} \\
(-2.42)\end{array}$ \\
\hline _cons & $\begin{array}{c}6.420^{* * * *} \\
(23.29) \\
\end{array}$ & $\begin{array}{c}6.615^{* * * *} \\
(41.25) \\
\end{array}$ & $\begin{array}{c}2.017^{* * * *} \\
(3.91) \\
\end{array}$ & $\begin{array}{l}6.970^{* * * *} \\
(103.59) \\
\end{array}$ & $\begin{array}{l}-1.220 \\
(-1.09) \\
\end{array}$ & $\begin{array}{c}6.967^{* * * *} \\
(123.48) \\
\end{array}$ \\
\hline$N$ & 33989 & 33989 & 33989 & 33989 & 33989 & 33989 \\
\hline N_bank & 1860 & 1860 & 1860 & 1860 & 1860 & 1860 \\
\hline $\mathrm{r} 2$ & 0.00968 & 0.0376 & 0.00510 & 0.00240 & 0.0196 & 0.188 \\
\hline
\end{tabular}

Notes: $t$ statistics in parentheses

${ }^{*} p<0.1,{ }^{* *} p<0.05,{ }^{* * *} p<0.01$

Our non-linear regression is shown in table 2. Our results show that there is an inverted $\mathrm{U}$ shaped in the relationship between LDR and economic development variables. Our main variables of interest are LDR and LDR2. We find that in OLS regression, in the beginning, LDR increases poverty, but after some point of threshold, it reduces poverty. It implies that finance could be a tool as poverty alleviation subject to a long-term condition. Our fixed effect regression shows that LDR 
increases regional GDP but reduces regional GDP after some point of the threshold. It indicates that too much finance is detrimental to regional economic growth in Indonesia, in line with Soedarmono et al. (2017).

Table 4: Non-linear Regression

\begin{tabular}{|c|c|c|c|c|c|c|}
\hline & $\begin{array}{c}\text { OLS } \\
\text { GDRP }\end{array}$ & $\begin{array}{c}\text { OLS } \\
\text { Inpoverty }\end{array}$ & $\begin{array}{c}\text { RE } \\
\text { GDRP }\end{array}$ & $\begin{array}{c}\text { RE } \\
\text { Inpoverty }\end{array}$ & $\begin{array}{c}\text { FE } \\
\text { GDRP }\end{array}$ & $\begin{array}{c}\text { FE } \\
\text { Inpoverty }\end{array}$ \\
\hline Idr & $\begin{array}{c}-0.00531 \\
(-1.37)\end{array}$ & $\begin{array}{c}0.0275^{\text {**** }} \\
(3.50)\end{array}$ & $\begin{array}{c}0.00676 \\
(1.28)\end{array}$ & $\begin{array}{c}0.000440 \\
(0.52)\end{array}$ & $\begin{array}{c}0.0103^{* *} \\
(1.97)\end{array}$ & $\begin{array}{c}0.000433 \\
(0.51)\end{array}$ \\
\hline ldr2 & $\begin{array}{c}0.0000336 \\
(1.34)\end{array}$ & $\begin{array}{c}-0.000163^{* * *} \\
(-3.19)\end{array}$ & $\begin{array}{c}-0.0000386 \\
(-1.12)\end{array}$ & $\begin{array}{c}-0.00000312 \\
(-0.56)\end{array}$ & $\begin{array}{c}-0.0000592^{*} \\
(-1.75)\end{array}$ & $\begin{array}{c}-0.00000309 \\
(-0.55)\end{array}$ \\
\hline roa & $\begin{array}{c}-0.00953^{* * *} \\
(-7.72)\end{array}$ & $\begin{array}{c}0.0747^{* * *} \\
(30.83)\end{array}$ & $\begin{array}{c}-0.0193^{* * *} \\
(-8.60)\end{array}$ & $\begin{array}{c}0.000127 \\
(0.46)\end{array}$ & $\begin{array}{c}-0.0167^{* * *} \\
(-7.44)\end{array}$ & $\begin{array}{c}0.000107 \\
(0.38)\end{array}$ \\
\hline NPL & $\begin{array}{c}-0.00119 \\
(-1.55)\end{array}$ & $\begin{array}{c}0.0107^{* * *} \\
(6.88)\end{array}$ & $\begin{array}{c}0.00778^{* * * *} \\
(4.59)\end{array}$ & $\begin{array}{c}0.000570^{* * * *} \\
(2.90)\end{array}$ & $\begin{array}{c}0.00709^{* * *} \\
(4.09)\end{array}$ & $\begin{array}{c}0.000569^{* * *} \\
(2.90)\end{array}$ \\
\hline car & 0.000357 & $0.00382^{* * *}$ & $0.00195^{\text {*** }}$ & 0.00000144 & $0.00111^{* *}$ & $\begin{array}{c}0.00000072 \\
9 \\
(0.01)\end{array}$ \\
\hline $\begin{array}{l}\text { Bank_- } \\
\text { Density }\end{array}$ & $-0.0111^{* * *}$ & $0.00548^{* * *}$ & $-0.0366^{* * *}$ & $0.0131^{* * *}$ & $-0.0731^{* * *}$ & $0.0131^{* * *}$ \\
\hline & $(-31.58)$ & $(8.60)$ & $(-20.55)$ & $(32.44)$ & $(-20.41)$ & (32.42) \\
\hline Inta & $\begin{array}{c}0.0122^{* * * *} \\
(2.79)\end{array}$ & $\begin{array}{c}-0.00142 \\
(-0.16)\end{array}$ & $\begin{array}{l}0.300^{* * *} \\
(17.91)\end{array}$ & $\begin{array}{c}-0.00313 \\
(-1.03)\end{array}$ & $\begin{array}{l}0.318^{* * *} \\
(14.46)\end{array}$ & $\begin{array}{c}-0.00314 \\
(-1.03)\end{array}$ \\
\hline eqta & $\begin{array}{c}0.0811^{* * * *} \\
(3.07)\end{array}$ & $\begin{array}{c}-0.532^{* * *} \\
(-9.80)\end{array}$ & $\begin{array}{c}0.271^{\text {**** }} \\
(4.26)\end{array}$ & $\begin{array}{c}0.0337^{* * * *} \\
(3.66)\end{array}$ & $\begin{array}{c}0.258^{* * *} \\
(3.77)\end{array}$ & $\begin{array}{c}0.0338^{* * * *} \\
(3.68)\end{array}$ \\
\hline Inflation & $\begin{array}{c}0.0285^{* * *} \\
(4.04)\end{array}$ & $\begin{array}{c}0.136^{* * *} \\
(10.38)\end{array}$ & $\begin{array}{c}0.00384 \\
(1.01)\end{array}$ & $\begin{array}{c}-0.00155^{\text {*** }} \\
(-2.45)\end{array}$ & $\begin{array}{c}-0.00621 \\
(-1.62)\end{array}$ & $\begin{array}{c}-0.00155^{* *} \\
(-2.45)\end{array}$ \\
\hline _cons & $\begin{array}{l}6.049^{* * * *} \\
(36.81)\end{array}$ & $\begin{array}{l}5.697^{* * * *} \\
(17.18)\end{array}$ & $\begin{array}{c}1.436^{* * * *} \\
(4.03)\end{array}$ & $\begin{array}{c}6.954^{* * *} \\
(97.26)\end{array}$ & $\begin{array}{c}2.050^{\text {**** }} \\
(4.40)\end{array}$ & $\begin{array}{l}6.951^{* * *} \\
(113.54)\end{array}$ \\
\hline$N$ & 33989 & 33989 & 33989 & 33989 & 33989 & 33989 \\
\hline N_bank & 1860 & 1860 & 1860 & 1860 & 1860 & 1860 \\
\hline r2 & 0.0398 & 0.0378 & 0.0299 & 0.00241 & 0.221 & 0.188 \\
\hline
\end{tabular}

\section{CONCLUSION}

We investigate the relationship of the capacity of financial intermediation function of rural banks on economic development. We measure the financial intermediation function with rural bank LDR. We gauge economic development variables with regional GDP and the number of people living in poverty. We find that financial intermediation could boost economic development but also could be harmful. Our non-linear regression shows that too much finance could harm regional GDP growth but, in the long term, could help to reduce poverty. 
Our results provide some important policy implications that rural banks could contribute to economic development. We also find that rural banks' fundamental factors are also could contribute to economic development. Therefore, financial authorities could improve the performance of rural banks by highly supervising the risk and competition within provinces and industries.

\section{REFERENCES}

Banto, J. M., \& Monsia, A. F. (2020). Microfinance institutions, banking, growth and transmission channel: A GMM panel data analysis from developing countries. Quarterly Review of Economics and Finance. https://doi.org/10.1016/j.qref.2020.06.004

Beck, T., Demirgüç-Kunt, A., \& Levine, R. (2007). Finance, inequality and the poor. Journal of Economic Growth, 12(1), 27-49. https://doi.org/10.1007/s10887-007-9010-6

Beck, T., Lu, L., \& Yang, R. (2015). Finance and Growth for Microenterprises: Evidence from Rural China. World Development, 67, 38-56. https://doi.org/10.1016/J.WORLDDEV.2014.10.008

Berger, A. N., Goulding, W., \& Rice, T. (2014). Do small businesses still prefer community banks? Journal of Banking and Finance, 44(1), 264-278. https://doi.org/10.1016/j.jbankfin.2014.03.016

Burgess, R., \& Pande, R. (2005). Do Rural Banks Matter? Evidence from the Indian Social Banking Experiment. American Economic Review, 95(3), 780-795. https://doi.org/10.1257/0002828054201242

Chang, P. C., Jia, C., \& Wang, Z. (2010). Bank fund reallocation and economic growth: Evidence from China. Journal of Banking and Finance, 34(11), 2753-2766. https://doi.org/10.1016/j.jbankfin.2010.05.015

Donou-Adonsou, F., \& Sylwester, K. (2016). Financial development and poverty reduction in developing countries: New evidence from banks and microfinance institutions. Review of Development Finance, 6(1), 82-90. https://doi.org/10.1016/J.RDF.2016.06.002

Hasan, I., Koetter, M., \& Wedow, M. (2009). Regional growth and finance in Europe: Is there a quality effect of bank efficiency? Journal of Banking and Finance, 33(8), 1446-1453. https://doi.org/10.1016/j.jbankfin.2009.02.018

Hassan, M. K., Sanchez, B., \& Yu, J. (2011). Financial development and economic growth : New evidence from panel data. Quarterly Review of Economics and Finance, 51(1), 88-104. https://doi.org/10.1016/j.qref.2010.09.001

Hook, S., \& Singh, N. (2014). Does too much finance harm economic growth ? Journal of Banking Finance, 41, 36-44. https://doi.org/10.1016/j.jbankfin.2013.12.020

Koetter, M., \& Wedow, M. (2010). Finance and growth in a bank-based economy: Is it quantity or quality that matters? Journal of International Money and Finance, 29(8), 1529-1545. https://doi.org/10.1016/j.jimonfin.2010.05.015

Meslier-Crouzille, C., Nys, E., \& Sauviat, A. (2012). Contribution of Rural Banks to Regional Economic Development: Evidence from the Philippines. Regional Studies, 46(6), 775-791. https://doi.org/10.1080/00343404.2010.529117

Park, D., \& Shin, K. (2017). Economic Growth, Financial Development, and Income Inequality. Emerging Markets Finance and Trade, 53(12), 2794-2825. https://doi.org/10.1080/1540496X.2017.1333958 
Shaban, M., Duygun, M., Anwar, M., \& Akbar, B. (2014). Diversification and banks' willingness to lend to small businesses: Evidence from Islamic and conventional banks in Indonesia. Journal of Economic Behavior and Organization, 103, S39-S55. https://doi.org/10.1016/j.jebo.2014.03.021

Soedarmono, W., Hasan, I., \& Arsyad, N. (2017). Non-linearity in the finance-growth nexus: Evidence from Indonesia. International Economics, 150, 19-35. https://doi.org/10.1016/j.inteco.2016.11.003

Trinugroho, I., Risfandy, T., \& Ariefianto, M. D. (2018). Competition, diversification, and bank margins: Evidence from Indonesian Islamic rural banks. Borsa Istanbul Review, 18(4), 349358. https://doi.org/10.1016/j.bir.2018.07.006 